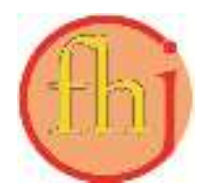

Faletehan Health Journal, 7 (3) (2020) 149-154

www. journal.Ippm-stikesfa.ac.id/ojs/index.php/FHJ

ISSN 2088-673X | e-ISSN 2597-8667

\title{
Inisiasi Menyusu Dini dan Pencapaian Involusi Uterus pada Ibu Postpartum
}

\author{
Riska Hediya Putri ${ }^{1 *}$, Surmiasih ${ }^{1}$, Feri Kameliawati ${ }^{1}$ Hanna Afifah $^{1}$ \\ ${ }^{1}$ Universitas Aisyah Pringsewu, Lampung, Indonesia \\ *Corresponding Author: riskahediya17@gmail.com
}

\begin{abstract}
Abstrak
Perdarahan portpartum menempati peringkat tertinggi pada angka kematian ibu. Salah satu penyebabnya adalah atonia uteri. Inisiasi menyusu dini (IMD) akan merangsang lobus posterior kelenjar pituitary untuk mensekresi hormon oksitosin. Oksitosin mempercepat proses involusi dan meminimalkan kehilangan darah. Tujuan penelitian ini untuk mengetahui pengaruh inisiasi menyusu dini terhadap pencapaian involusi uterus pada ibu postpartum. Penelitian ini bersifat kuantitatif dengan desain penelitian quasi eksperimen. Subjek penelitian yaitu ibu postpartum dengan sampel penelitian sebanyak 16 kasus dan 16 kontrol. Teknik sampling concecutive sampling. Analisa data menggunakan uji $t$ independent. Hasil penelitian didapatkan bahwa ibu postpartum yang melakukan IMD setelah 2 jam didapatkan rata rata tinggi fundus $3,13 \mathrm{~cm}$ dibawah pusat dan setelah 12 jam didapatkan rata - rata 2,13 cm dibawah pusat dan kelompok yang tidak IMD yaitu setelah 2 jam dan 12 jam didapatkan hasil sama yaitu rata - rata 1,63 cm dibawah pusat. Hasil analisa bivariat pada kedua kelompok setelah 2 jam dilakukan IMD didapatkkan p-value $=0,000$ dan setelah 12 jam IMD didapatkan $\mathrm{p}$-value $=0,030$. Hal ini dapat disimpulkan bahwa ada hubungan inisiasi menyusu dini terhadap pencapaian involusi uterus pada ibu postpartum, sehingga peneliti menyarankan untuk menjadikan IMD sebagai SOP dalam setiap pelayananan persalinan.
\end{abstract}

Kata Kunci: Inisiasi Menyusu Dini, Involusi Uteri, Postpartum

\section{Early Initiation of Breastfeeding and Achievement of Postpartum Uterine Involution}

\begin{abstract}
Postpartum hemorrhage gets the highest rank in the maternal mortality rate. One of the causes is uterine atony. Early initiation of breastfeeding can induce posterior lobe of pituitary gland to secret oxytocin. Oxytocin accelerates the involution process and minimizes blood loss. The research aims to identify the effects of early initiation of breastfeeding on uterine involution process in post-partum mothers. It is a quantitative research with quasi-experimental research design. The samples are postpartum mothers, 16 cases and 16 controls. The sampling technique used consecutive sampling. The data analysis used independent $t$-test. The results of the research found that the post-partum mothers who did early initiation of breastfeeding after two hours had the average of fundal height $3.13 \mathrm{~cm}$ below bellybutton and after twelve hours had the average of $2.13 \mathrm{~cm}$ below bellybutton. The group that did not do early initiation of breastfeeding after two hours and twelve hours got the same result of average $1.63 \mathrm{~cm}$ below bellybutton. The results of the bivariate analysis in both groups after two hours got $p$-value 0.000 and after twelve hours obtained $p$-value 0.030 . It can be concluded that there is an effect of early initiation of breastfeeding on uterine involution process in post-partum mothers. Thus, the researchers suggested to make early initiation of breastfeeding as a standard operational procedure in childbirth service.
\end{abstract}

Keywords: Early Initiation of Breastfeeding, Uterus Involution, Post-Partum 


\section{Pendahuluan}

Angka Kematian Ibu karena perdarahan postpartum mempunyai peringkat tertinggi dimana salah satu penyebab perdarahannya adalah atonia uteri. Bila uterus pada ibu postpartum mengalami kegagalan dalam involusi akan menyebabkan sesuatu yang disebut subinvolusio yang sering disebabkan oleh infeksi dan tertinggalnya sisa plasenta dalam uterus sehingga proses involusi uterus tidak berjalan normal atau terhambat. Bila subinvolusio tidak tertangani akan menyebabkan perdarahan yang berlanjut atau Postpartum haemorrhage hingga kematian (Absari \& Riyanti, 2020).

Involusi uteri merupakan perubahan retrogreaf pada uterus yang menyebabkan berkurangnya ukuran uterus, involusi puerperium dibatasi pada uterus dan apa yang terjadi pada organ dan struktur lain hanya dianggap sebagai perubahan puerperium (Varney et al., 2007). Faktor - faktor yang mempengaruhi involusi uterus yaitu laktasi, mobilisasi dini, gizi ibu hamil (pengetahuan, lingkungan, kepercayaan, sosial budaya masyarakat) paritas, psikologi, menyusui dini, dan usia (Lisnawaty et al., 2015).

Inisiasi Menyusu Dini (IMD) atau permulaan menyusui dini adalah bayi mulai menyusui sendiri segera setelah lahir. Inisiasi menyusu dini dan pengisapan puting payudara oleh bayi pada awal masa nifas memperkuat stimulasi pengeluaran oksitosin. Ketika bayi menghisap puting, refleks saraf merangsang lobus posterior kelenjar pituitary untuk mensekresi hormon oksitosin. Oksitosin mempercepat proses involusi dan meminimalkan kehilangan darah (Roesli, 2012).

Inisiasi Menyusu Dini merupakan memberikan ASI segera setelah bayi dilahirkan, biasanya dalam waktu 30 menit sampai satu jam setelah bayi lahir. Inisiasi menyusu dini (IMD) juga berperan dalam pencapaian tujuan Sustainable Development Goals (SDGs), khususnya pada tujuan ketiga, yakni memastikan kehidupan yang sehat dan mendukung kesejahteraan bagi semua untuk semua usia, dengan target mengurangi rasio angka kematian ibu dan bayi pada tahun 2030 (Badan Pusat Statistik, 2016). Menurut hasil Riset Kesehatan Dasar (Riskesdas) tahun 2013, di Indonesia angka IMD mengalami peningkatan, yaitu dari 29,3\% pada tahun 2010 menjadi $34,5 \%$ pada tahun 2013. Menurut riset ini pula, kebanyakan proses inisiasi menyusui dini ini terjadi antara 1-6 jam setelah proses kelahiran. Cakupan IMD berdasarkan Rikesdas 2013 provinsi Lampung menduduki urutan ke-6 Inisiasi Menyusui Dini (IMD) terendah se-Indonesia dan masih dibawah data cakupan nasional (Kemenkes RI, 2014). Data dari Kementerian Kesehatan Republik Indonesia (Kemenkes) tahun 2015 menunjukkan bahwa dari 100.000 kelahiran hidup di Indonesia, 305 di antaranya berakhir dengan kematian sang ibu (Kemenkes RI, 2015). Mayoritas kasus kematian ibu atau sekitar 75\% dari total kasus kematian ibu adalah pendarahan, infeksi, tekanan darah tinggi saat kehamilan, komplikasi persalinan, dan aborsi yang tidak aman (Say et al., 2014).

Keberhasilan atau kegagalan dalam pelaksanaan IMD dipengaruhi oleh beberapa faktor antara lain adalah ibu bersalin menghadapi banyak hambatan untuk melakukan IMD terhadap bayi yang diperoleh di tempat persalinan, kurangnya dukungan yang diberikan keluarga, serta banyaknya ibu yang belum dibekali pengetahuan yang cukup tentang manfaat dari pelaksanaan IMD. Selain itu keberhasilan program Inisiasi Menyusu Dini (IMD) juga sangat dipengaruhi oleh sikap, pengetahuan dan motivasi bidan/dokter penolong persalinan itu sendiri. Kurangnya pengetahuan dari orang tua, pihak medis maupun keengganan untuk melakukannya membuat Inisiasi Menyusu Dini masih jarang dipraktikkan. Banyak orang tua yang merasa kasihan dan tidak percaya seorang bayi yang baru lahir dapat mencari sendiri susu ibunya. Ataupun rasa malu untuk meminta dokter yang membantu persalinan untuk melakukannya (Roesli, 2012).

Menurut penelitian Hadi \& Fairus (2017) yang berjudul faktor- faktor yang berhubungan dengan involusi uterus pada ibu postpartum di wilayah kerja Puskesmas Ketapang Lampung 
Faletehan Health Journal, 7 (3) (2020) 142-148

www. journal.Ippm-stikesfa.ac.id/ojs/index.php/FHJ

ISSN 2088-673X | 2597-8667

Utara, mnunjukkan bahwa tidak ada hubungan; umur dan paritas dengan involusi uterus. Ada hubungan inisiasi menyusu dini dan mobilisasi dini dengan involusi uterus. Observasi tinggi fundus uterus dalam penelitian ini dilakukan dalam penelitian ini dilakukan pada hari ke-10 setelah persalinan. Sedangkan selama 1 sampai 2 jam pertama postpartum intensitas kontraksi uterus bisa berkurang dan menjadi teratur. Karena itu penting sekali menjaga dan mempertahankan kontraksi uterus pada masa ini. Suntikan oksitosin biasanya diberikan secara intravena atau intramuskuler segera setelah kepala bayi lahir. Namun dengan melakukan IMD segera setelah bayi lahir akan merangsang pelepasan oksitosin karena hisapan bayi pada payudara. Oleh karena itu dalam penelitian ini obervasi yang dilakukan pada 2 jam dan 12 jam setelah persalinan.

\section{Metode Penelitian}

Desain penelitian menggunakan metode kuantitatif dengan pendekatan quasi eksperimen dalam dua kelompok (independent pair). Subjek penelitian adalah ibu postpartum. Variabel objek penelitian ini inisiasi menyusu dini (IMD) dan pencapaian involusi uterus. Populasi dalam penelitian ini adalah seluruh pasien postpartum yang melahirkan pada bulan Februari tahun 2018 di BPM "A" dan BPM "B" dengan rata-rata kunjungan pada di BPM " $A$ " sebanyak 11 sampai 15 persalinan dan BPM "B" sebanyak 10 sampai 15 persalinan. Rumus sampel penelitian menggunakan penghitungan sampel untuk uji hipotesis beda rata-rata pada 2 kelompok independen. Hasil perhitungan sampel dalam penelitian didapatkan hasil sebanyak minimal 8 responden disetiap kelompok, dengan ktiteria sampel yaitu ibu dengan persalinan normal dan nilai apgar bayi baru lahir normal yaitu $7-10$. Namun saat penelitian persalinan pada bulan Februari hingga Maret tahun 2018 didapatkan ibu bersalin di BPM "A" sebanyak 16 persalinan dan di BPM "B" sebanyak 23 persalinan sehingga peneliti menggunakan 16 sampel untuk setiap kelompok. Teknik sampling menggunakan concecutive sampling. Penentuan responden didasarkan pada standar operasional prosedur (SOP) yang ada di BPM. Ibu postpartum BPM "A" dijadikan kelompok intervensi dikarenakan terdapat SOP pemberian IMD dalam tindakan proses persalinan dan ibu postpartum di BPM "B" dijadikan kelompok kontrol dikarenakan belum ada SOP tetap dalam tindakan proses persalinan.

Jenis data yang digunakan adalah data primer yang diambil dari lembar observasi. Observasi yang dilakukan dengan melakukan pengukuran fundus uterus pada ibu postpartum sebanyak dua kali yaitu dua jam setelah diberikan perlakuan dan 12 jam setelah diberikan perlakuan. Selama proses penelitian, peneliti dibantu asisten bidan (enumerator) dengan diberikan pelatihan pengukuran fundus uterus sebelumnya untuk menyamakan persepsi terhadap peneliti. Pada kelompok kasus, peneliti melakukan observasi secara mandiri, namun pada kelompok kontrol peneliti hanya melakukan pengukuran fundus uterus pada 9 ibu postpartum dan 7 lainnya dibantu oleh asisten bidan (enumerator). Analisis data pada penelitan ini dengan menggunakan analisis data univariat untuk mengetahui gambaran rata-rata pencapaian involusi uterus dan analisa bivariat dengan uji $t$ independent.

\section{Hasil dan Pembahasan \\ Tabel 1. Rata - Rata Pencapaian Involusi Uterus}

\begin{tabular}{|c|c|c|c|}
\hline Kelompok & $\begin{array}{c}\text { Pencapaian } \\
\text { Involusi }\end{array}$ & $\begin{array}{c}\text { Rata } \\
- \\
\text { rata }\end{array}$ & $\begin{array}{c}\text { Perbedaan } \\
\text { rata - rata } \\
\text { (IK 95\%) }\end{array}$ \\
\hline \multirow{2}{*}{$\begin{array}{l}\text { Dilakukan } \\
\text { IMD }\end{array}$} & $\begin{array}{c}\text { Setelah } 2 \\
\text { jam }\end{array}$ & 3,13 & $2,74-3,51$ \\
\hline & $\begin{array}{c}\text { Setelah } 12 \\
\text { jam }\end{array}$ & 2,13 & $1,74-2,51$ \\
\hline \multirow{2}{*}{$\begin{array}{l}\text { Tidak } \\
\text { dilakukan } \\
\text { IMD }\end{array}$} & $\begin{array}{c}\text { Setelah } 2 \\
\text { jam }\end{array}$ & 1,63 & $1,36-1,89$ \\
\hline & $\begin{array}{c}\text { Setelah } 12 \\
\text { jam }\end{array}$ & 1,63 & $1,36-1,89$ \\
\hline
\end{tabular}

Diketahui dari 16 responden yang melakukan IMD setelah 2 jam persalinan didapatkan rata - rata pencapaian involusi uterus sebesar $3,13 \mathrm{~cm}$ dibawah pusat dan setelah 12 jam didapatkan rata - rata 2,13 cm dibawah pusat. Dari hasil ini diketahui bahwa ada kenaikan involusi uterus pada ibu postpartum yang melakukan IMD antara 2 jam setelah IMD dengan 12 jam setelah IMD. Hasil berbeda pada 16 responden yang tidak melakukan IMD, pencapaian involusi uterus setelah 2 jam dan 12 jam pasca persalinan didapatkan hasil sama yaitu rata-rata $1,63 \mathrm{~cm}$ dibawah pusat.

Penelitian yang dilakukan Sahetapy (2016), didapatkan hasil pada kelompok perlakuan IMD setelah 12 jam pasca persalinan rata - rata involusi 
uterus sebesar 3,34 dan kelompok kontrol, setelah 12 jam rata - rata involusi uterus sebesar 2,04. Selama 1 sampai 2 jam pertama postpartum intensitas kontraksi uterus bisa berkurang dan menjadi teratur. Karena itu penting sekali menjaga dan mempertahankan kontraksi uterus pada masa ini. Pemberian ASI segera setelah bayi lahir akan merangsang pelepasan oksitosin karena hisapan bayi pada payudara (Indrasari, 2019).

Oksitosin merupakan zat yang dapat merangsang myometrium uterus sehingga dapat berkontraksi. Kontraksi uterus merupakan suatu proses yang kompleks dan terjadi karena adanya pertemuan aktin dan myosin. Pertemuan aktin dan myosin disebabkan karena adanya myocin light chainkinase (MLCK) dan dependent myosin ATP ase, proses ini dapat dipercepat oleh banyaknya ion kalsium yang masuk di dalam sel, sedangkan oksitosin merupakan suatu hormone yang memperbanyak masuknya ion kalsium ke dalam intra sel sehingga dengan adanya oksitosin akan memperkuat kontraksi uterus (Setiani Lucy \& Sumarni, 2016). Involusi uterus dapat diamati dari luar dengan memeriksa fundus uteri segera setelah melahirkan tinggi fundus uteri $2 \mathrm{~cm}$ dibawah pusat, 12 jam kemudian kembali $1 \mathrm{~cm}$ diatas pusat dan menurun kira - kira $1 \mathrm{~cm}$ setiap hari (Absari \& Riyanti, 2020)

Kualitas pelaksanaan Inisias Menyusu Dini dipengaruhi oleh terpenuhi atau tidaknya tahapan pelaksanaan Inisias Menyusu Dini, berdasarkan Protokol evidence-based yang baru telah diperbaharui tentang asuhan bayi baru lahir untuk satu jam pertama, Jika proses Inisiasi Menyusu Dini dilaksanakan berdasarkan Protokol evidencebased maka proses pelaksanaan IMD dapat dikatakan berkualitas (Pesak et al., 2017). Faktorfaktor yang mempengaruhi involusi uterus yaitu laktasi, mobilisasi dini, gizi, pengetahuan, lingkungan, kepercayaan, sosial budaya masyarakat, paritas, psikologi, menyusu dini. Menyusu dini merupakan salah satu faktor pendukung terjadinya proses involusi uterus karena dengan memberikan air susu ibu kepada bayi segera setelah melahirkan sampai satu jam pertama, memberikan efek kontraksi pada otot polos uterus (Lisnawaty et al., 2015).

Pada penelitian ini menunjukkan bahwa pemberian ASI sedini mungkin melalui IMD dan pemberian ASI sesering mungkin menyebabkan gerakan menghisap yang berirama yang akan menghasilkan rangsangan saraf yang terdapat pada glandula pituitaria posterior, sehingga keluar hormon oksitosin. Hal ini menyebabkan sel-sel mioepitel disekitar alveoli akan berkontraksi dan mendorong ASI masuk dalam ampula. Pengeluaran oksitosin selain dipengaruhi oleh isapan bayi, juga oleh reseptor yang terletak pada duktus. Bila duktus melebar, maka secara reflektoris oksitosin dikeluarkan oleh hipofisis

\section{Tabel 2. Perbedaan Pencapaian Involusi} Uterus Setelah 2 Jam IMD

\begin{tabular}{lccc}
\hline $\begin{array}{c}\text { Pencapaian } \\
\text { Involusi } \\
\text { Uterus }\end{array}$ & Mean & P-value & IK 95\% \\
\hline $\begin{array}{l}\text { Setelah 2 jam } \\
\text { IMD }\end{array}$ & 3,13 & 0,000 & 1,5 \\
& & & $\begin{array}{c}(1,053- \\
1,947)\end{array}$ \\
$\begin{array}{l}\text { Setelah 2 jam } \\
\text { tidak IMD }\end{array}$ & 1,63 & & \\
\hline
\end{tabular}

Tabel 3. Perbedaan Pencapaian Involusi Uterus Setelah 12 Jam IMD

\begin{tabular}{lccc}
\hline $\begin{array}{c}\text { Pencapaian } \\
\text { Involusi } \\
\text { Uterus }\end{array}$ & Mean & P-value & IK 95\% \\
\hline $\begin{array}{l}\text { Setelah 12 jam } \\
\text { IMD }\end{array}$ & 2,13 & 0,030 & 0,5 \\
& & & $\begin{array}{c}(0,053- \\
0,947)\end{array}$ \\
$\begin{array}{l}\text { Setelah 12 jam } \\
\text { tidak IMD }\end{array}$ & 1,63 & & \\
\hline
\end{tabular}

Hasil uji statistik pada tabel 2 dan 3 diketahui bahwa pada kedua kelompok setelah 2 jam dilakukan IMD didapatkkan pvalue $=0,000$ dan setelah 12 jam IMD didapatkan $\mathrm{p}$ value $=0,030$, sehingga dapat disimpulkan terlihat ada pengaruh inisiasi menyusu dini terhadap pencapaian involusi uterus setelah 2 jam dan 12 jam pasca persalian.

Hasil penelitian ini sejalan dengan penelitian yang dilakukan Nelwatri (2015), yang bertujuan untuk mengetahui perbedaan rata rata tinggi fundus uteri antara yang dilakukan IMD dan tidak IMD. Hasil penelitan tersebut didapatkan perbedaan tinggi fundus uteri yang signifikan antara yang dilakukan IMD dan tidak dilakukan IMD pada ibu bersalin di BPS Kota Padang. Penelitian lain yang dilakukan oleh Mantasia (2017) di RSUD H.Padjonga Dg Ngalle Kab.Takalar, menunjukkan bahwa terdapat perbedaan kadar hormon oksitosin pada ibu yang melakukan IMD dan ibu yang tidak melakukan IMD. Rata-rata kadar hormon oksitosin ibu pada kelompok perlakuan (IMD berhasil) 
Faletehan Health Journal, 7 (3) (2020) 142-148

www. journal.Ippm-stikesfa.ac.id/ojs/index.php/FHJ

ISSN 2088-673X | 2597-8667

$232.9583 \mathrm{ng} / \mathrm{ml}$ dan pada kelompok Kontrol (IMD tidak berhasil) $217.0034 \mathrm{ng} / \mathrm{ml}$. yang berarti bahwa meskipun secara statistik tidak mempunyai hubungan yang signifikan namun secara garis besar tetap lebih tinggi kadar hormon oksitosin pada ibu yang IMD dibandingkan yang tidak.

Adanya hormon oksitosin yang dirangsang melalui putting susu memberikan efek kontraksi pada otot polos sehingga terjadi percepatan perubahan uterus kembali ke normal. Manfaat yang bisa didapat dengan melakukan IMD salah satunya adalah membantu pengeluaran plasenta, mempercepat perubahan uterus kembali normal dan mencegah pendarahan disebabkan sentuhan, kuluman dan jilatan bayi pada puting susu ibu akan merangsang sekresi hormon oksitosin yang penting menyebabkan kontraksi rahim yang membantu pengeluaran plasenta dan mengurangi pendarahan sehingga mencegah anemia, serta merangsang hormon lain yang membuat ibu menjadi tenang, rileks dan mencintai bayinya serta merangsang pengaliran ASI dari payudara (Roesli, 2012). Involusi uterus dipengaruhi oleh adanya kontraksi uterus yang terjadi segera setelah bayi lahir, sebagai akibat kontraksi ini rahim akan mengecil kembali dan disertai rasa mules. Involusi uterus pada ibu bersalin yang melakukan IMD umumnya berlangsung secara cukup cepat dibandingkan dengan ibu yang tidak melakukan IMD.

\section{Simpulan}

Penelitian ini menunjukkan bahwa penatalaksanaan IMD akan sangat membantu proses involusi uterus, sehingga IMD dapat dijadikan standar prosedur operasional dalam melakukan pertolongan persalinan, terutama bagi fasilitas kesehatan dan tenaga kesehatan yang belum melaksanakan IMD saat menolong persalinan.

\section{Referensi}

Absari, N., \& Riyanti, D. N. (2020). Pengaruh Mobilisasi Dini terhadap Involusi Uterus pada Ibu Post Partum di Wilayah Kerja Puskesmas O Mangunharjo Kabupaten Musi Rawas. Jurnal Kebidanan Harapan Ibu Pekalongan, 7(1), 27-31. https://doi.org/10.37402/jurbidhip.vol7.iss1.7 0

Badan Pusat Statistik. (2016). Potret awal tujuan pembangunan berkelanjutan (Sustainable development goals) di Indonesia. Badan Pusat
Statistik.

Hadi, Y., \& Fairus, M. (2017). Faktor- Faktor Yang Berhubungan Dengan Involusi Uterus Pada Ibu Post Partum Di Wilayah Kerja Puskesmas Ketapang Lampung Utara. Jurnal Kesehatan Metro Sai Wawai, 7(2), 1-7. https://doi.org/10.26630/JKM.V7I2.548

Indrasari, N. (2019). Meningkatkan Kelancaran ASI dengan Metode Pijat Oksitoksin pada Ibu Post Partum. Jurnal Ilmiah Keperawatan Sai Betik, 15(1), 48. https://doi.org/10.26630/jkep.v15i1.1325

Kemenkes RI. (2014). InfoDATIN situasi dan analisis ASI Eksklusif. Kementrian Kesehatan.

Kemenkes RI. (2015). Profil kesehatan Indonesia tahun 2014. Kementrian Kesehatan RI.

Lisnawaty, Ernawati, \& Hasmawati. (2015). Faktor - Faktor Yang Mempengaruhi Involusi Uterus Pada Ibu Post Partum Di Rumah Sakit Khusus Daerah Ibu Dan Anak Pertiwi. Jurnal Ilmiah Kesehatan Diagnosis, 7(5), 565-571.

Mantasia, N. (2017). Pengaruh Inisiasi Menyusu Dini (Imd) Terhadap Kadar Hormon Oksitosin Dan Proses Involusio Uteri Pada Ibu Post Partum Resiko Tinggi Di Rsud H.Padjonga Dg Ngalle Kab. Takalar. Voice of Midwifery, 07(09), 97-103. https://journal.umpalopo.ac.id/index.php/Vo M/article/view/34

Nelwatri, H. (2015). Pengaruh Inisiasi Menyusu Dini (IMD) Terhadap Involusi Uterus Pada Ibu Bersalin Di BPS Kota Padang Tahun 2013. Jurnal Ipteks Terapan, 8(3), 83-87. https://doi.org/10.22216/jit.2014.v8i3.2

Pesak, E., Losu, F. N., \& Sulawesiana, W. (2017). Determinan Penerapan Inisiasi Menyusu Dini Oleh Bidan Berdasarkan Evidence Based Di Puskesmas Rawat Inap Kota Tomohon. Jurnal Ilmiah Bidan, 5(1), 1-11.

Roesli, U. (2012). Panduan: inisiasi menyusu dini: plus asi eksklusif. Pustaka Bunda.

Sahetapy, S. Y. (2016). Pengaruh Inisiasi Menyusu Dini (IMD) terhadap Kecepatan Involusio Uterus pada Ibu Nifas di BPM Dwi Inggrini Samarinda. Mahakam Midwifery Journal, 1(I), 1-9.

Say, L., Chou, D., Gemmill, A., Tunçalp, Ö., Moller, A. B., Daniels, J., Gülmezoglu, A. M., Temmerman, M., \& Alkema, L. (2014). Global causes of maternal death: A WHO systematic analysis. The Lancet Global Health, 2(6), e323-e333. 
Faletehan Health Journal, 7 (3) (2020) 149-154

www. journal.Ippm-stikesfa.ac.id/ojs/index.php/FHJ ISSN 2088-673X | 2597-8667

https://doi.org/10.1016/S2214109X(14)70227-X

Setiani Lucy, I., \& Sumarni. (2016). Perbedaan Efektivitas Pijat Oksitosin Dan Relaksasi Hypnobirthing Terhadap Involusi Uterus Pada
Ibu Post Partum Di Puskesmas Rawalo Pada Tahun 2015. Jurnal Ekologi KesehatanKebidanan, 06(11), 40-46.

Varney, H., Kriebs, J., \& Gegor, C. (2007). Buku ajar asuhan kebidanan. EGC. 